\title{
List of Tables
}

Table 1

Table 2

Table 1.1

Table 1.2

Table 1.3

Table 1.4

Table 1.5

Table 2.1

Table 2.2

Table 2.3

Table 2.4

Table 3.1

Table 3.2

Table 3.3

Table 3.4

Table 3.5

Table 3.6

Table 3.7

Table 3.8

Table 3.9

AElfwine's Devotions to the Holy Cross - 36

The Office of the Blessed Virgin Mary in AElfwine's

Prayerbook - 38

Orationes ad personas Trinitatis: the basic six prayers to the Trinity and Virgin - 43

The Orationes ad personas Trinitatis in a select manuscript record, emphasizing the distinctions between the early Carolingian and later Anglo-Saxon sources - 47

The prayers of the Eadui Psalter, showing the prayers to the Trinity and saints $-\mathbf{5 7}$

Personal liturgical programs in the Galba Prayerbook (listed in Muir, Prayer-Book) - 64

A plan of the central part of AElfwine's Prayerbook, showing later additions -74

De laude psalmorum - 91

Latin analogues to the Prayers ad horas identified by R. A. Banks - 108

The conventional Prayers ad horas sequence and its appearance in a select manuscript record - 112

The Prayers ad horas in three manuscripts - $\mathbf{1 1 6}$ In honore sanctae crucis: the Special Office of the Holy Cross in Alfwine's Prayerbook - $\mathbf{1 4 0}$

Oratio in .l. mane ad crucem: a possible Office of the Holy Cross in Alfwine's Prayerbook (Cotton Titus D XXVII, fols. $72 r-73 v)-143$

A comparison of the antiphons used in five prayer programs dedicated to the cross -144

Texts for the Regularis concordia liturgy of the Veneration of the Cross $-\mathbf{1 5 0}$

The Veneration program in the Galba Prayerbook — 152

Prayers to the cross in Tiberius A III (based on Cooper, Monk-Bishops) - 155

The first Veneration program in Tiberius A III, fols. $58 r-59 r-155$

The second Veneration program in Tiberius A III, fols. $114 \mathrm{v}-115 \mathrm{v}-157$

The private prayers in the Portiforium of St. Wulstan, indicating the prayers to the cross $-\mathbf{1 5 8}$ 
Table 3.10 The prayer programs based on the Veneration of the Cross in the Portiforium of St. Wulstan - 159

Table 3.11 The private prayers in the Eadui Psalter, indicating the prayers to the cross 166

Table 4.1 A possible prayer program for use against enemies on some damaged leaves in the Galba Prayerbook — 187

Table 5.1 Prayers in the Portiforium of St. Wulstan, pp. 581-618, indicating the confessional prayers (based on Hughes, ed., Portiforium, vol. 2) 254

Table 5.2 A group of confessional prayers in Tiberius A III (based on Cooper, Monk-Bishops) -257 